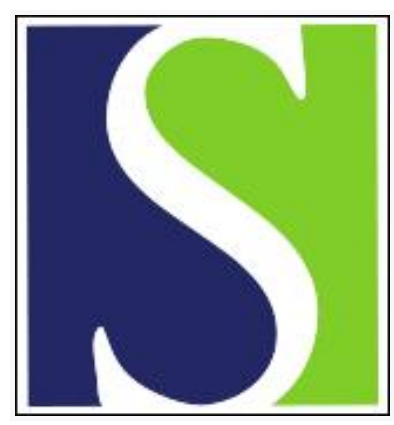

Scand J Work Environ Health 1976;2(2):107-114

https://doi.org/10.5271/sjweh.2819

Issue date: Jun 1976

Systolic time intervals as a measure of left ventricular function in viscose rayon workers exposed to carbon disulfide. by Franco G, Malamani T

Key terms: carbon disulfide; carbon disulfide intoxication; left ventricular; left ventricular function; myocardial contractility; myocardium; occupational disease; systolic time interval; viscose rayon; viscose rayon worker

This article in PubMed: www.ncbi.nlm.nih.gov/pubmed/959790

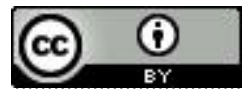




\title{
Systolic time intervals as a measure of left ventricular function in viscose rayon workers exposed to carbon disulfide
}

\author{
by GIULIANO FRANCO, M.D., and TULLIO MALAMANI, M.D. ${ }^{1}$
}

\begin{abstract}
FRANCO, G. and MALAMANI, T. Systolic time intervals as a measure of left ventricular function in viscose rayon workers exposed to carbon disulfide. Scand. $j$. work environ. \& health 2 (1976) 107-114. In a group of viscose rayon workers exposed to carbon disulfide the systolic time intervals were calculated. They were determined from the simultaneous recording of an ECG, a phonocardiogram, and arterial pulse tracings. Results indicate a shortened left ventricular ejection time (LVET) and a prolonged isovolumetric contraction time (ICT), together with an increase in the ratio of ICT to LVET. These alterations, which occurred in the absence of any clinical signs or symptoms of heart disease, are interpreted as a consequence of an impaired left ventricular contractility, comparable to mild coronary dysfunction. Literature data support the hypothesis that the biochemical mechanisms involved in the effect of carbon disulfide on myocardial cells are (a) an interference with energy metabolism from the inadequate availability of thiamine and nicotinamide or a direct inhibition of cytochrome or (b) an interference with catecholamine metabolism and defective hormonal control of the energy utilization process. Impaired left ventricular function in rayon viscose workers exposed to carbon disulfide represents an early and highly sensitive sign of carbon disulfide intoxication, and the use of systolic time intervals as a noninvasive measure of myocardial performance may be a useful method for monitoring carbon disulfide exposed people.
\end{abstract}

Key words: carbon disulfide intoxication, systolic time intervals, myocardium, myocardial contractility, occupational diseases.

The first observations of myocardial anatomopathological alterations in animals poisoned experimentally with carbon disulfide $\left(\mathrm{CS}_{2}\right)$ go back to 1930 (6). Forty years later epidemiologic studies established a significant correlation between chronic occupational $\mathrm{CS}_{2}$ exposure and increased risk of death from coronary heart disease. In viscose rayon workers exposed to $\mathrm{CS}_{2}$, when compared with nonexposed workers, there was evidence of a 2.5 to 3 -fold excess mortality $(28,33)$.

1 Institute of Occupational Health, University of Pavia, Pavia, Italy.

Reprint requests to: Dr. Giuliano Franco, Istituto di Medicina del Lavoro, dell'Università di Pavia, via Severino Boezio, $24-$ Pavia, Italia.
In addition to these retrospective observations, a Finnish team of investigators followed, starting in 1967 , a group of 343 workers from a viscose rayon factory. The first results showed a higher prevalence of angina, a higher mean systolic and diastolic blood pressure, and a slightly higher, but nonsignificant prevalence of pathological ECG signs, while blood lipids were not significantly altered (18, 20). The next stage confirmed the excess mortality from coronary heart disease in the $\mathrm{CS}_{2}$ exposed group: 16 men died against 3 in the comparison group (19). During the next stage of follow up, a high incidence of angina, present in $25 \%$ of the $\mathrm{CS}_{2}$ exposed subjects, and coronary mortality and a higher mean value of blood pressure was registered, while 
there was no difference between coronary signs of exposed and nonexposed subjects in ECGs evaluated by Minnesota codes (34). The problem of ECG changes in viscose rayon workers is controversial, and no definitive conclusions can be drawn from existing data. More recent studies have shown an increased prevalence of coronary ECG findings $(10,17,35)$ and nonspecific changes in comparison with healthy subjects of the same age and social class $(14,32)$.

The data strongly support the hypothesis of an association between chronic exposure to $\mathrm{CS}_{2}$ and an increased risk for developing coronary heart disease. Furthermore, a prolonged exposure to toxic levels increases the incidence of coronary heart disease and worsens the prognosis of it. Nevertheless the toxic effect on the heart may not always be clearly demonstrated, except when clinical signs of angina or myocardial infarction, as well as ECG changes of such events, are present.

Therefore an attempt to create a method capable of monitoring early signs of heart dysfunction through the study of cardiovascular phenomena in $\mathrm{CS}_{2} \mathrm{ex}-$ posed subjects appears worthwhile. For this purpose it is necessary that the method of evaluating myocardial function reveal impaired contractility, even in the absence of clinically manifested heart disease. A large number of techniques have been proposed for evaluating $d y-$ namic myocardial function of the heart. However, none has achieved universal acceptance. Left ventricular performance has been recently evaluated with external atraumatic techniques, and measurement of the systolic time intervals calculated from recordings of the ECG, phonocardiogram and carotid pulse tracing have gained much popularity over the last 15 years. In patients with advanced left ventricular disease, as in heart failure and myocardial infarction, the preejection period (PEP) and the isovolumetric contraction time (ICT) are usually prolonged, while the left ventricular ejection time (LVET) is shortened $(16,29,36,37)$. Two simple composites of systolic time intervals, the ratio of PEP to LVET and the ratio of ICT to LVET, have correlated with ejection fraction and with end diastolic volume in pa-
Table 1. Range of the measured carbon disulfide $\left(\mathrm{CS}_{2}\right)$ concentrations in the factory and the number of subjects examined.

\begin{tabular}{|c|c|c|}
\hline Work site & $\begin{array}{c}\text { Range of } \mathrm{CS}_{2} \\
\text { concentrations } \\
\left(\mathrm{mg} / / \mathrm{m}^{3}\right)\end{array}$ & $\begin{array}{l}\text { Number } \\
\text { of } \\
\text { subjects }\end{array}$ \\
\hline \multirow{3}{*}{$\begin{array}{l}\text { Churn room } \\
\text { Spinning room } \\
\text { Washing, desulfuring, } \\
\text { and bleaching sites }\end{array}$} & $20-40$ & 7 \\
\hline & $40-60$ & 8 \\
\hline & $10-20$ & 3 \\
\hline
\end{tabular}

tients with coronary heart disease, and they appear to separate patients with severe coronary artery disease and those with functionally mild disease from normal persons $(16,31)$. The ICT/LVET appears to be the best index for predicting left ventricular contractility in patients with mitral disease (5) or chronic coronary heart disease (7).

In the present study the cardiac function in $\mathrm{CS}_{2}$ exposed subjects was assessed with the evaluation of left ventricular contractility as measured by systolic time intervals.

\section{MATERIAL AND METHODS}

Eighteen exposed subjects, whose ages ranged from 47 to 59 years (mean 54 years) were examined. They had worked under exposed conditions in a rayon viscose factory from 8 to 23 years (mean 18 years). $\left(\mathrm{CS}_{2}\right.$ concentrations in the factory were constantly below the threshold limit value of $60 \mathrm{mg} / \mathrm{m}^{3}$ accepted in Italy; the range of the measured $\mathrm{CS}_{2}$ concentrations is reported in table 1.)

The small number of $\mathrm{CS}_{2}$ exposed subjects is due to the necessity to select workers, in order to exclude subjects presenting disease able to determine by itself changes in the systolic time intervals. Examined subjects did not present any of the following clinical features: history of probable or typical angina, diabetes mellitus (1), chronic obstructive bronchopneumopathy $(12,21)$, coronary heart disease as evaluated with the Minnesota code (7, 34 ), systolic blood pressure higher than $155 \mathrm{~mm} \mathrm{Hg}$, sum of the contraction time and half relaxation time of the ankle 
jerk reflex of more than $380 \mathrm{~ms}(8,13)$. Excluding workers with these clinical symptoms should have eliminated any factor capable of affecting systolic time intervals $(2,7,12,13,21)$, and therefore any systolic time interval changes found should be caused by exposure to $\mathrm{CS}_{2}$. Twenty-two metal arc welding workers, whose ages ranged from 42 to 61 years (mean 56 years), were selected from a machine factory for the reference group. They had never been exposed to $\mathrm{CS}_{2}$.

With Weissler's method $(36,37)$ the duration of the phases of the left ventricular systole was measured from the simultaneous recording of the ECG, the phonocardiogram, and the carotid and femoral arterial pulse tracings with a Mingograph 81 (Elema Schoenander) recorder at a paper speed of $100 \mathrm{~mm} / \mathrm{s}$ (fig. 1). The ECG lead used was $D_{9}$. For recording the phonocardiogram a piezoelectric microphone (EIMT 25 B) was placed over the mesocardium so that the initial high frequency vibration of the first and second sound could be distinguished. Carotid arterial pulse was recorded with a Boucke-Brecht capacitive transducer (EMT 439); femoral arterial pulse was recorded with a Marey's capsule connected by a polyethylene tube to a transducer (EMT $510 \mathrm{C}$ ).

The following systolic time intervals were measured directly (fig. 1): (a) the total electromechanical systolic interval $\left(\mathrm{QS}_{2}\right)$ from the onset of the $q$ wave in $\mathrm{D}_{2}$ to the first vibration of the aortic component of the second heart sound; (b) the left ventricular ejection time (LVET) from the beginning upstroke to the incisura of the carotid arterial pulse trac-

Fig. 1. Simulaneous recording of an electrocardiogram $\left(\mathrm{D}_{2}\right)$, a phonocardiogram, and carotid and femoral pulse tracings. The recording illustrates the direct measurement of the total electromechanical systolic interval $\left(\mathrm{QS}_{2}\right)$, the left ventricular ejection time (LVET), the interval between the first $\left(\mathrm{S}_{1}\right)$ and the second $\left(\mathrm{S}_{2}\right)$ heart sound, the delay of the sphygmic wave $(R)$, and the calculation of the preejection period (PEP), the interval from the beginning of depolarization to the first heart sound $\left(\mathrm{QS}_{1}\right)$, and the isovolumetric contraction time (ICT). Systolic time intervals are expressed in milliseconds. ing; (c) the interval between the first $\left(\mathrm{S}_{1}\right)$ and the second $\left(\mathrm{S}_{2}\right)$ heart sound from the onset of the first heart sound to the beginning of the aortic component of the second heart sound; (d) the interval between the upstroke of the carotid and the upstroke of the femoral arterial pulse tracings $(R)$, delay of the sphygmic wave. Indirectly from the directly made measurements the following time intervals were calculated: (e) the preejection period (PEP), derived by subtracting the LVET from the $\mathrm{QS}_{2}$ interval; (f) the interval from the beginning of depolarization to the
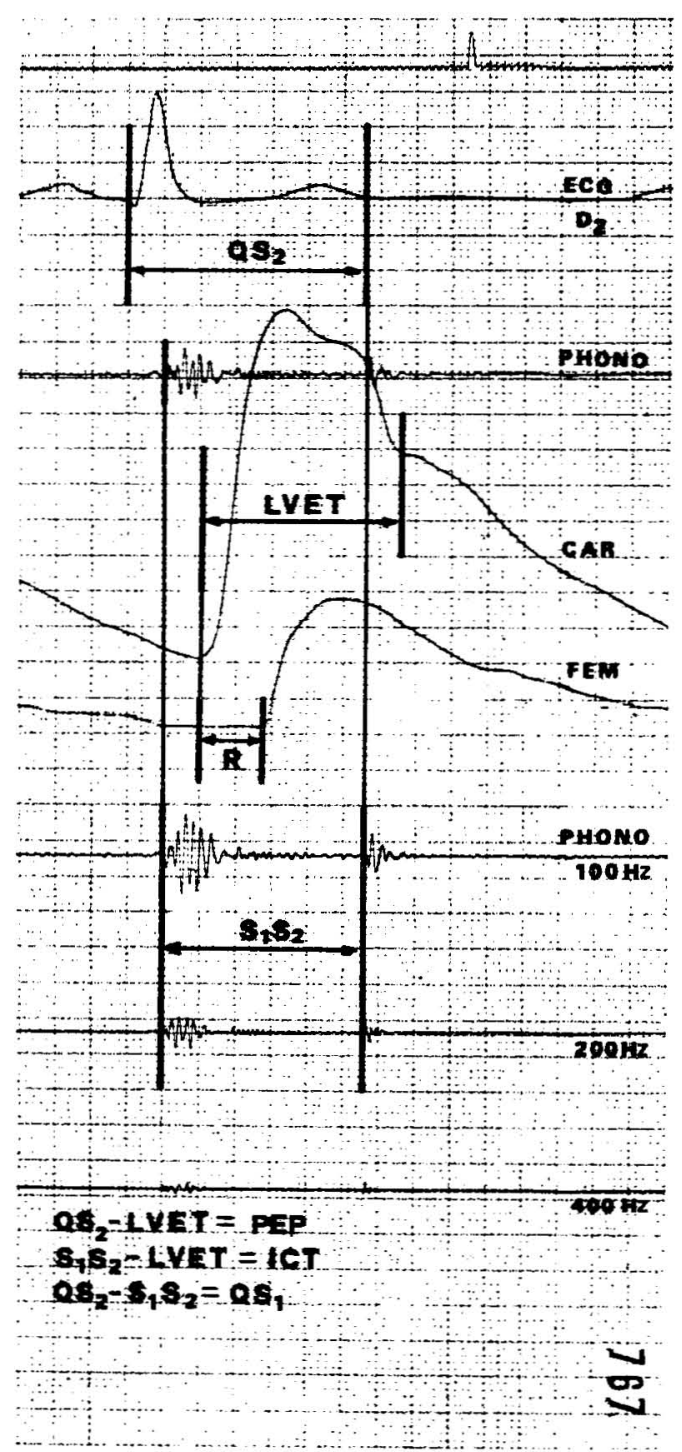
first heart sound $\left(Q_{1}\right)$, derived by subtracting $\mathrm{S}_{1} \mathrm{~S}_{2}$ from $\mathrm{QS}_{2}$; and (g) the isovolumetric contraction time (ICT), derived by subtracting LVET from $\mathrm{S}_{1} \mathrm{~S}_{2}$.

Intervals were calculated as the average of at least 10 consecutive systoles. Heart rate was calculated from the following relationship: 60 per average $R R$ interval.

The normal value for systolic time intervals predicted for heart rate were calculated from the regression equation of Weissler $(36,37)$. Deviations from the normal data were calculated as the difference between the observed values and that predicted for heart rate from the normal regression equation. The differences in the deviations from the normal regression equation are expressed in milliseconds as $\triangle Q^{2}, \quad \triangle L V E T, \triangle S_{1} S_{2}$, $\triangle \mathrm{PEP}, \triangle \mathrm{QS}_{1}$; ICT needed no correction for heart rate $(36,37)$. In addition the ratios between PEP and LVET and between ICT and LVET, not corrected for heart rate, were calculated.

We calculated sphygmic wave rate by dividing the time between the upstroke of the carotid pulse and the upstroke of the femoral pulse (R) by the distance, obtained from the difference between the sum of the jugular point - umbilicus segment plus umbilicus - carotid pulse segment minus the carotid pulse point jugular segment (38).

The average of the differences obtained from the normal regression data in the $\mathrm{CS}_{2}$ exposed group and in the reference group was calculated with the Student's t-test.

\section{RESULTS}

The results are presented in table 2 . In the $\mathrm{CS}_{2}$ exposed group the LVET and ICT were significantly shortened $(P<0.01)$. Also $\mathrm{QS}_{2}$ appeared to be shortened, but not significantly $(\mathrm{P}<0.1)$. The changes in $\mathrm{S}_{1} \mathrm{~S}_{2}(\mathrm{P}<0.2)$, $\mathrm{PEP}(\mathrm{P}<0.3)$ and $\mathrm{QS}_{1}$ $(P<0.2)$ were nonsignificant. The mean value of the ratio PEP/LVET of the $\mathrm{CS}_{2}$ exposed group did not greatly differ from that of the nonexposed group $(\mathrm{P}<0.2)$, while the increased mean value of the ratio ICT/LVET, resulting from the simultaneous shortened LVET and prolonged

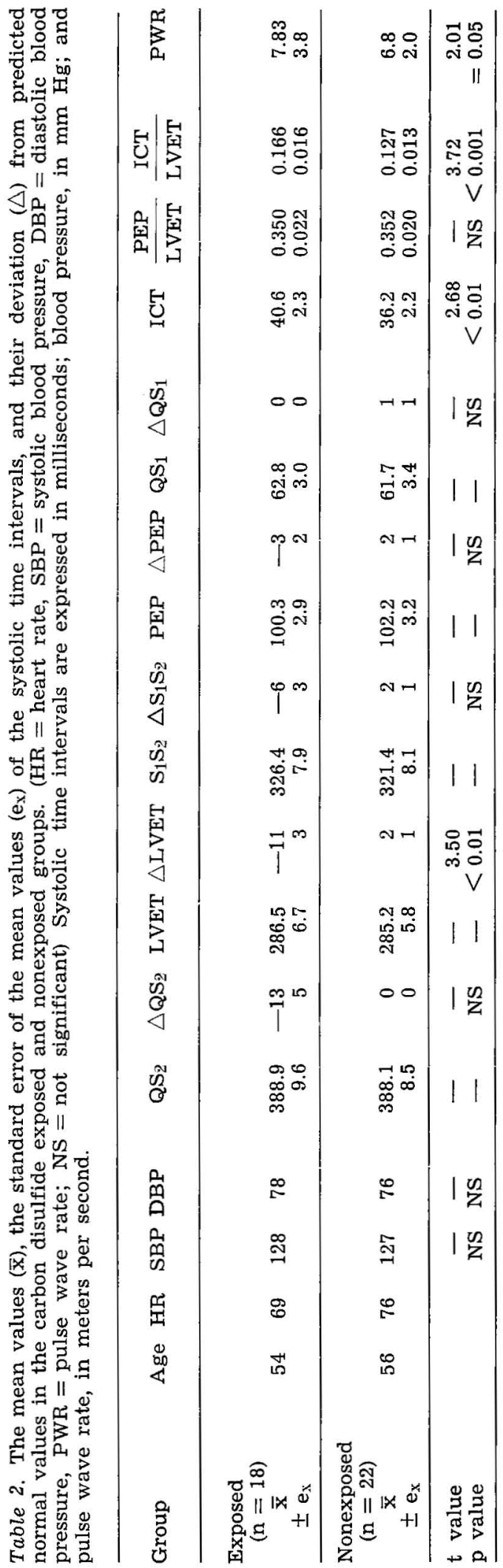


ICT, was highly significant $(P<0.001)$. There was no significant correlation between the parameters of the ratios ICT/ LVET $(r=-0.07)$ and PEP/LVET $(r=$ 0.012 ).

The sphygmic rate of the $\mathrm{CS}_{2}$ exposed group was increased in comparison with the nonexposed group. However the significance of the difference appeared to be critical $(P=0.05)$. The preceding observations must to be confirmed and explained with further investigation.

\section{DISCUSSION}

Previous studies have demonstrated that an impaired myocardial contractility determines a shortened LVET and a prolonged PEP and ICT, the latter by decreasing the rise of isovolumetric pressure rise $(7,27,36)$. Instead, when myocardial contractility increases, the rate of development of tension too increases, and thus the ICT shortens (3). Observations on the relationship between systolic time intervals and direct measures of left ventricular performance, assessed angiographically, have revealed a correlation between LVET, PEP, ICT, and the end diastolic volume and the ejection fraction $(2,16)$, but it was concluded that, "ICT is the interval most intimately related to contractility" (2). The measure of ICT and the determination of the ratio of ICT to LVET appear to be the best indices for predicting a left ventricular contractility and for detecting contractile deficits which may exist in the absence of clear clinical symptoms $(2,27)$.

Results of the present study showed a prolonged ICT, a shortened LVET, and an increased ratio of ICT to LVET, all of which indicate an impaired myocardial function. The impairment is similar, but lesser in grade, to the well-documented impairment found in various heart diseases $(7,24,31)$. In coronary heart disease and heart failure an extensively shortened LVET, an extensively prolonged PEP, and an increased value for the ratios PEP/LVET and ICT/LVET $(7,36)$ have been observed. The PEP, composed of two subdivisions, the ICT, and the $\mathrm{QS}_{1}$ interval did not show any significant deviation in the $\mathrm{CS}_{2}$ exposed group. A prolonged ICT alone (not accompanied by a prolonged $\mathrm{QS}_{1}$ ) was insufficient to determine a prolongation of PEP and, hence, an increased PEP/ LVET.

$\mathrm{CS}_{2}$ exposure appears to be associated with a decreased rate of isovolumetric pressure rise and therefore with a decreased myocardial contractility. Our results revealed an impaired myocardial contractility in $\mathrm{CS}_{2}$ exposed workers, in whom it was impossible to find any other feature which may have influenced systolic time intervals. This finding would suggest that the toxin exerts a direct effect on myocardial cells and leads to a diminished contractility that may account for a deficit in the number, organization, and synchronism of myocardial cells. Myocardial cells contain more mitochondria than any other cells in the body - evidence of the tremendous energy required for contraction. The transfer of energy from oxygen to ATP depends upon mitochondrial integrity, including the enzyme of the intermediary citric acid cycle, the respiratory oxidative chain, and the cytochrome system. Any interference with the enzymatic systems involved in the oxidative metabolism leads to defective ATP production and utilization and results in a progressive decrease in cardiac contractile force.

At least four biochemical mechanisms may account for $\mathrm{CS}_{2}$ toxic action on the myocardial tissue: (a) deficiency of thiamine, an essential component of the decarboxilation enzymes; (b) deficiency of nicotinamide, an essential constituent of NAD and NADP; (c) inhibition of the respiratory cytochrome system; and (d) interference with catecholamine metabolism.

In experimental $\mathrm{CS}_{2}$ poisoning and in occupational $\mathrm{CS}_{2}$ intoxication, clinical features of generalized neuropathy, similar to those present in beriberi, have been documented $(22,23)$. The hypothesis of a thiamine deficiency in $\mathrm{CS}_{2}$ intoxicated subjects is supported by the observation of decreased thiamine content in liver and muscle found in $\mathrm{CS}_{2}$ poisoned rats (4). Resulting interference with the oxidative cycle and ATP deficiency is noted all through the body, especially in the highly 
ATP-dependent cardiac muscle, and may cause abnormalities in myocardial contractility.

In $\mathrm{CS}_{2}$ poisoned animals an increased excretion of nicotinamide metabolites (49) and a decrease of blood and skeletal muscle nucleotides $(40,41)$ were observed. No studies exist regarding heart content of NAD and NADP; however, the literature suggests that $\mathrm{CS}_{2}$ exposure provokes an inadequate availability of nicotinamide and leads to abnormalities in mitochondrial electron transfer and, finally, to reduced contractile efficiency.

Various chemical substances $(-\mathrm{CN}, \mathrm{CO}$, BAL, barbiturates) may inhibit the enzymes of the respiratory chain. In vitro $\mathrm{CS}_{2}$ inhibits the cytochrome oxidase system (30); in $\mathrm{CS}_{2}$ poisoning a depression of the oxidative metabolism of the liver (15) and a loss of cytochrome oxidase of myocardial tissue after the administration of subtoxic doses of noradrenaline (9) have also been observed. These toxicological aspects of $\mathrm{CS}_{2}$ interference with the respiratory oxidative chain and the cytochrome system would suggest that $\mathrm{CS}_{2}$ is responsible for a reduced availability and utilization of energy required for myocardial contraction.

The interference of $\mathrm{CS}_{2}$ with catecholamine metabolism (a temporary increase of dopamine level in the brain of $\mathrm{CS}_{2}$ poisoned rats) has been observed as a consequence of an inhibition of dopamine $\beta$ hydroxylase (26). In addition myocardial lesions caused by subtoxic doses of noradrenaline in $\mathrm{CS}_{2}$ exposed rats show that $\mathrm{CS}_{2}$ affects the catecholamine metabolism in the myocardial tissue $(9,26)$. The increased amount of coronary heart disease among workers exposed to $\mathrm{CS}_{2}$ might be explained by a derangement in catecholamine metabolism $(25,26)$. In this way, through an interference with the hormonal control via the adenyl cyclase (11), $\mathrm{CS}_{2}$ may justify the abnormal myocardial contractility in $\mathbf{C S}_{2}$ exposed people.

Present findings reveal alterations of some parameters considered to be valid measures of myocardial contractility in $\mathrm{CS}_{2}$ exposed workers, in the absence of clinical symptoms of heart failure or coronary heart disease. The literature suggests that $\mathrm{CS}_{2}$ may affect the heart either by interfering with the enzymatic systems, the interference leading to a defective energy compound production (the involved enzymatic systems would be the tricarboxylic acid cycle enzymes and the respiratory chain enzymes) through a deficiency of thiamine and nicotinamide or a direct inhibition of cytochrome, or by interfering with the catecholamine metabolism, which would lead to an impaired hormonal control of energy utilization.

Findings of a prolonged ICT, an increased ICT/LVET ratio and a shortened LVET, unassociated with clinically manifested cardiopathy, may be interpreted as an early mechanical deficit in myocardial function, otherwise not detectable. These data support the use of systolic time intervals as a noninvasive measure of left ventricular performance for the evaluation of impaired myocardial contractility by any systolic time interval change in workers exposed to $\mathrm{CS}_{2}$. This method may represent a new way of monitoring early signs of $\mathrm{CS}_{2}$ intoxication.

\section{REFERENCES}

1. AHMED, S. S., JAFERI, G. A., NARANG, A. M. and REGAN, T. J. Preclinical abnormality of left ventricular function in diabetes mellitus. Am. heart j. 89 (1975) 89-153.

2. AHMED, S. S., LEVINSON, G. E., SCHWARTZ, C. J. and ETTINGER, P. O. Systolic time intervals as measure of the contractile state of the left ventricular myocardium in man. Circulation 46 (1972) $559-571$.

3. AMIDI, M., LEON, D. F., DE GROOT, W. J., KROETZ, F. W. and LEONARD, J. J. Effect of the thyroid state on myocardial contractility and ventricular ejection rate in man. Circulation 38 (1968) 229-239.

4. ANDREUZZI, P. and MAGGI, G. C. Sulla correlazione fra carenza tiaminica ed intossicazione solfocarbonica nel ratto. Acta vitaminol. 13 (1959) 103-107.

5. ARONOW, W. S., KAPLAN, M. A. and ELLENSTAD, M. H. LVET/EICT index in mitral valve disease. Acta cardiol. 26 (1971) $1-10$.

6. AUDO GIANOTTI, G. B. Ricerche anatomopatologiche sull'intossicazione sperimentale da solfuro di carbonio. Rass. med. appl. lav. ind. 1 (1930) 165-183.

7. BƯYÜKÖZTƯRK, K., KIMBRIS, D., KINGSLEY, B. and SEGAL, B. L. Left 
ventricular function in chronic coronary heart disease: The value of the ICT/LVEP ratio. G. ital. cardiol. 2 (1972) 191-201.

8. CAVALLERI, A., TACCOLLA, A., GRAOVAC-LEPOSAVIC, L., MAUGERI, U. and DJURIC, D. The serum tyroxine and the achilles tendon reflex in workers exposed to carbon disulphide. Med. lav. 62 (1971) $412-415$.

9. CHANDRA, S. V., BUTLER, W. H. and MAGOS, L. Effect of carbon disulfide on the myocardium of the rat. Exp. mol. pathol. 17 (1972) 249-259.

10. CIRLA, A., VILLA, A. and TOMASINI, M. Indagine sull'incidenza di coronaropatie nei lavoratori di un'industria di viscosa rayon, esposti a solfuro di carbonio. Med. lav. 63 (1972) $431-441$.

11. ENTMAN, M. L., LEWEY, G. S. and EPSTEIN, S. R. Mechanism of the action of epinephrine and glucagon on the canine heart: Evidence for increase in sarcotubular calcium stores mediated by cyclic 3', 5' AMP. Cir. res. 25 (1969) 429-438.

12. FRANCO, G., MALAMANI, T., PRESTINONI, A. and GHETTI, G. L'efficienza contrattile del ventricolo sinistro nella broncopneumopatia cronica ostruttiva. Cardiol. prat. In press.

13. FRANCO, G., MALAMANI, T. and ZELASCHI, G. P. Il calcolo dei tempi sistolici come indice di funzionalità tiroidea. Minerva med. In press.

14. FRANCO, G., RIZZO, S. and TACCOLA, A. Sulle alterazioni elettrocardiografiche nel solfocarbonismo: l'indice di Macruz nei soggetti esposti. Med lav. 64 (1973) 444 446.

15. FREUNDT, K. J. and KURZINGER, R. Energy potential and hepatic function in rats under acute exposure to carbon disulphide. Int. Arch. Arbeitsmed. 34 (1975) $269-282$.

16. GARRARD, C. L., WEISSLER, A. M. and DODGE, $H$. T. The relationship of alterations in systolic time intervals to ejection fraction in patients with cardiac disease. Circulation 42 (1970) 455-462.

17. GOTO, S. and HOTTA, R. The medical and hygienic prevention of carbon disulphide poisoning in Japan. In: H. BRIEGER and J. TEISINGER (eds.), Toxicology of carbon disulphide. Excerpta Medica Foundation, Amsterdam 1967, pp. 219-230.

18. HERNBERG, S., NORDMAN, C.-H., PARTANEN, T., CHRISTIANSEN, V. and VIRKOLA, P. Blood lipids, glucose tolerance, and plasma creatinine in workers exposed to carbon disulphide. Work-environ. -health 8 (1971) 11-16.

19. HERNBERG, S., NURMINEN, M. and TOLONEN, M. Excess mortality from coronary heart disease in viscose rayon workers exposed to carbon disulphide. Work-environ.health 10 (1973) 93-99.

20. HERNBERG, S., PARTANEN, T., NORDMAN, C.-H. and SUMARI, P. Coronary heart disease among workers exposed to carbon disulphide. $\mathrm{Br}$. j. ind. med. 28 (1970) $313-325$.

21. HOOPER, R. G. and WHITCOMB, M. E.
Systolic time intervals in chronic obstuctive pulmonary disease. Circulation 50 (1974) 1205-1209.

22. LEWEY, F. H. Experimental chronic carbon disulphide poisoning in dogs. J. ind. hyg. toxicol. 23 (1941) 415-436.

23. LEWEY, F. H. Neurological, medical and biochemical signs and symptoms indicating chronic industrial carbon disulphide poisoning. Ann. int. med. 15 (1941) 869-876.

24. LEWIS, R. P., MARCUS, D. R., GARRARD, C. L. and WEISSLER, A. M. Abnormal systolic time intervals with normal cardiac output in chronic myocardial disease. Circulation 42 (1970): suppl. III, 65.

25. MAGOS, L. Toxicity of carbon disulphide. Ann. occup. hyg. 15 (1972) 303-309.

26. MAGOS, L., GREEN, A. and JARVIS, J. E. A. Half life of $\mathrm{CS}_{2}$ in rats in relation to its effect on brain catecholamines. Int. Arch. Arbeitsmed. 32 (1974) 289-296.

27. METZGER, C. C., CHOUGH, C. B., KROETZ, F. W. and LEONARD, J. J. True isovolumic contraction time: Its correlation with two external indexes of ventricular performance. Am. j. cardiol. 25 (1970) 434-442.

28. MOWE, G. Coronary heart disease and occupational exposure to carbon disulphide. In: D. DJURIC, L. GRAOVAC'-LEPOSAVIC, A. POŠTICGRUJIN and M. STANKOVIC (eds.), Abstract: II international symposium on toxicology of carbon disulphide. Banja Koviljaca, 25-28 May, 1971. Institute of Occupational and Radiological Health, Beograd 1971.

29. ORESHKOV, V. Indirect measurement of isovolumetric contraction time on the basis of polygraphic tracings. Cardiologia 47 (1965) 315-321.

30. PEIZKER, Z. Vstřebávání, metabolismus a púsobení sirouhlíku v organismu. VIII. Vliy sirouhlíku na cytochromoxydasový systém. Pracov. lék. 6 (1954) 17-19.

31. PERRY, J. M. and GARRARD, C. L. Systolic time intervals: Relation to severity of coronary artery disease and left ventricular disfunction. Circulation 42 (1970): suppl. III, 121.

32. TACCOLA, A., CAVALLERI, A., FRANCO, G. and MALAMANI, T. Electrocardiographic changes in $\mathrm{CS}_{2}$ exposed workers. 3rd International symposium on toxicology of carbon disulphide. Cairo-Alexandria, May 4-9, 1974.

33. TILLER, J. R., SCHILLING, R. S. F. and MORRIS J. N. Occupational toxic factor in mortality from coronary heart disease. Br. med. j. 4 (1968) 407-411.

34. TOLONEN, M., HERNBERG, S., NURMINEN, M. and TIITOLA, K. A follow-up study of coronary heart disease in viscose rayon workers exposed to carbon disulphide. Br. j. ind. med. 32 (1975) 1-10.

35. TOMASINI, M., CHIAPPINO, G. and SPOTTI, D. Indagine sull'incidenza di coronaropatie in pensionati ex - lavoratori di una industria di viscosa - rayon esposti a solfuro di carbonio. Med. lav. 65 (1974) $368-378$. 
36. WEISSLER, A. M., HARRIS, W. S. and SCHOENFELD, C. D. Systolic time intervals in heart failure in man. Circulation 37 (1968) 149-159.

37. WEISSLER, A. M., HARRIS, W. S. and SCHOENFELD, C. D. Bedside technics for evaluation of ventricular function in man Am. j. cardiol. 23 (1969) 577-583.

38. WEZLER, K., BÖGER, A. Über einen neuen Weg zur Bestimmung des absoluten Schlagvolumens des Herzens beim Menschen auf Grund der Windkesseltheorie und seine experimentelle Prüfung. Arch. Exp. Pathol. Pharmakol. 184 (1937) $482-505$

39. WRONSKA-NOFER, T., GORNY, R., SOKAL, J. A., SOBCZAK, H. and SZYC,
M. Metabolites of nictotinamide and nicotinic acid in urine of rats in course of carbon disulphide poisoning. Med. lav. 64 (1973) 13-19.

40. WROÑSKA-NOFER, T. and SOKAL, J. A. The levels of nicotinamide adenine dinucleotides in the tissue of rabbits and rats after chronic exposure to carbon disulphide. Int. Arch. Arbeitsmed. 29 (1972) 124-128.

41. WROŃSKA-NOFER, T., STETKIEWICZ, $J$. and SZENDZIKOWSKI, S. Structural alterations and content of nicotinamide adenine nucleotides in skeletal muscle of rat in chronic experimental carbon disulphide intoxication. Int. Arch Arbeitsmed. 31 (1973) 123-134.

Received for publication: 1975-04-11 